\title{
L'ACTOR I LA MEMÒRIA. ARTS ESCÈNIQUES, CREATIVITAT I NEUROCIÈNCIES
}

\author{
Martí B. FONS SASTRE (ed.)
}

(Palma de Mallorca: Fundació ESADIB, 2016, 146 págs.)

Comenta Maurice Halbawachs en su magnífico libro sobre la memoria colectiva que esta se construye sobre los recuerdos que todos y cada uno de nosotros tenemos de nuestra infancia, de nuestras vivencias reales $\mathrm{u}$ oníricas, de nuestra familia y de nuestro entorno en el sentido más amplio del término. Una memoria que es selectiva y que se nutre esencialmente de las emociones que, en última instancia, sirven para crear nuestra identidad o identidades de acuerdo con nuestras fases existenciales.

Identidad. Recuerdos. Vivencias. Nostalgia. Olvido. Colectividad. Historia. Hegemonía. Subversión. Oralidad. Microhistorias. Mitos. Imaginarios culturales. Teatro. Actor. Una gradación conceptual que ha servido a la investigación interdisciplinaria para construir y definir los mecanismos de transmisión secular de la cultura en plural y para delimitar la jerarquización de los sistemas sociales y generacionales ligados a la memoria, formada de manera habitual por microhistorias que se transmiten bien a través de una tradición oral bien en forma escrita. Y una gradación que también ha sido reivindicada por la escritura dramática y por distintas teorías teatrales de enorme trascendencia para la evolución de las artes escénicas.

El teatro-documento propugnado por Peter Weiss a mediados de los años 60 del pasado siglo y ampliamente desarrollado por los teatros independientes de la siguiente década es un buen ejemplo de ello. Como también lo es la dramaturgia generada a partir del relato de microhistorias 
aportadas por voces silenciadas a las que los autores o los directores de escena darán visibilidad mostrando las relaciones entre el individuo y su realidad política, social o existencial. En definitiva, un "teatro de la memoria" y un "teatro para la memoria".

Sin embargo, los más que claros ejemplos que podamos esbozar (y evidentemente extender) de la literatura dramática se tornan extremadamente complejos cuando nos referimos al proceso creador del actor en su construcción de un ser vivo diferente a sí mismo llamado personaje que también tiene vivencias y recuerdos y al que el actor debe encarnar en el sentido físico del término pero también en el sentido espiritual y trascendente. Un misterio ritual, el de la creación, al que han intentado dar respuesta los grandes teórico-prácticos del teatro. Desde Stanislavski, Meyerhold y Michael Chejov hasta Eugenio Barba, solo por mencionar a algunos de ellos, todos los sistemas, escuelas o trainings actorales se han servido de los conceptos a los que hemos aludido anteriormente aunque con nomenclaturas total o parcialmente distintas: memoria emocional, psicofísica, biomecánica, imaginación creativa, biología actoral, partituras gestuales y emocionales, cuerpo aculturizado y así sucesivamente. Pero más que respuestas, los textos de los grandes padres del teatro proponen nuevos cuestionamientos que ha intentado resolver la investigación teatral que abarcará la semiótica, la sociología y la antropología esencialmente hasta llegar a las más recientes aportaciones de las neurociencias.

Y es justamente en la intersección entre la teoría y la práctica, entre la investigación académica y la investigación creativa donde debemos situar el valor del texto editado por Martí B. Fons Sastre L'actor i la memoria (arts escèniques, creativitat i neurociències) cuyos redactores recogen la doble vertiente que hemos señalado. El libro debe ser considerado, pues, en una primera instancia, como una batería de posibles respuestas a ese ritual creador que es la interpretación.

Nacido bajo la tutela de una acción especial $\mathrm{R}+\mathrm{D}$ convocada por el Govern Balear a través de su Conselleria d'Educació, Universitat i Cultura y financiada por los fondos FEDER de la comunidad europea, el texto coordinado por Martín B. Fons es el resultado de los laboratorios teatrales organizados en este contexto con la finalidad de construir un espacio - que responderá a las siglas ERIC - en el que se dieran la mano la investigación, la innovación y la creación artística. Estos tres ejes serán los que delimiten los distintos bloques que encontramos en el texto. 
En el primero de ellos —artes escénicas, creatividad y neurocienciahallamos los trabajos de dos jóvenes investigadores, Gabriele Sofia y Martí B. Fons Sastre. Ambos se referirán de manera complementaria y sin fisuras al papel de las neurociencias cognitivas al estudio del proceso actoral. El primero establecerá en «Hipótesis para una historia de las relaciones entre teatro y neurociencia en el siglo XX» una cronología conceptual de las relaciones entre el trabajo del actor, la fisiología de las emociones y las neurociencias apelando a Copeau, Meyerhold, Stanislavski y Barba. El segundo realizará en "La actuación psicofísica: perspectivas artísticas y neurocientíficas" una disección pormenorizada de los elementos que conforman la dimensión psicofísica actoral y, de manera especial, el papel que desempeña la memoria como desencadenante creador. Dos textos que ya son de obligada mención en cualquier bibliografía que se precie al combinar el rigor académico con la precisión en el establecimiento del campo de trabajo, la metodología y la terminología que va más allá de la simple especulación y/o descripción para convertirse en una posible hoja de ruta para la práctica creativa. Algo de incalculable valor para la investigación en las artes escénicas.

De carácter sin duda más misceláneo, el segundo bloque —el actor y la memoria - reúne cuatro trabajos de carácter distinto por el origen y formación interpretativa de sus autores, pero coincidentes en el papel de la memoria tanto en trainings derivados de tendencias y estilos interpretativos específicos como en la utilización de determinados imaginarios culturales para la creación de imágenes individuales eminentemente sensoriales. Los trabajos firmados por Maite Villar y Pere Sais, titulados respectivamente "La memoria en el marco de las dramaturgias efímeras" y "Grotowski: el entrenamiento físico desde el Teatro Pobre a El Arte como vehículo", introducen también ordenadamente a dos grandes nombres de la escena contemporánea, Étienne Décroux y Jerzy Grotowsky. Lejos de ser considerados como capítulos independientes dentro del texto general, los trabajos de Villar y Sais son complementos-demostraciones de las reflexiones planteadas en el primer bloque del libro y como también lo será otro de los trabajos que firmará Lluís Valenciano en un bloque posterior del libro, que tendrá como protagonista al maestro ruso Meyerhold y que llevará como título "Reflexiones sobre la técnica interpretativa en el laboratorio del teatro físico y la memoria", cerrando ese círculo de conexiones que forman parte del ecosistema teórico actoral, si se nos permite la licencia de 
usar una expresión relacionada con las narrativas transmediáticas.

Y nos referíamos a cuatro trabajos en este bloque del actor y la memoria. Mientras unos van a ser teóricos, los restantes van a tener un carácter eminentemente práctico y ciertamente acorde con el tema del libro al detallar y relatar las experiencias de los autores en su trabajo escénico con los actores ya sea para la construcción de un espectáculo ya sea como parte de un taller-laboratorio. De este modo, Pere Fullana en su "Teatro del testimonio: realidad y dramaturgia de la memoria" reflexionará acerca del proceso de construcción del espectáculo L'experiència Queli (2016) como parte de una dramaturgia construida a partir de microhistorias vivenciales; y Cecilia Molano y Chus Domínguez nos ofrecerán la reconstrucción del «Diario de marzo», un texto que va más allá del diario de ensayos para transformarse en una crónica, en el sentido brechtiano del término, del proceso de reflexión que acompaña a la creación artística en la que los actores-creadores pondrán en funcionamiento no solo su imaginario individual sino también el banco de imágenes colectivo al servicio de la creación de nuevos productos culturales.

Un intercambio de la memoria en su concepto más amplio que se concretará en la tercera parte del libro - reflexiones de los participantes en los talleres/laboratorio - plagada de preguntas, divagaciones artísticas e inquietudes personales que las acciones formativo-investigadoras han suscitado en actores y docente en un cierre de un volumen compacto que cumple a la perfección con el objetivo de la investigación que no es el de dar respuestas categóricas sino el de suscitar nuevas cuestiones y elementos de reflexión. Por eso nos referíamos al iniciar esta reseña a «posibles» respuestas ya que el libro que reseñamos supone, desde nuestro punto de vista, un magnífico ejemplo de construcción de conocimiento en el campo de las artes escénicas.

Así, el libro L'actor $i$ la memòria (arts escèniques, creativitat $i$ neurociències) coordinado por Martí B. Fons Sastre es una rara avis en el panorama editorial de las artes escénicas por ir más allá de la simple erudición o de la descripción de procesos intangibles como es la creación actoral, el texto es el reflejo de un trabajo constante de reflexión y experimentación escénica llevada a cabo por parte del profesorado y el alumnado de la ESADIB (Escuela Superior de Arte Dramático de las Baleares) en el que creación e innovación se dan la mano con una clara voluntad de transferencia del conocimiento; un conocimiento que no es 
cuantificable económicamente pero sí culturalmente. Un trabajo y unos objetivos claros que se palpan en cada uno de los artículos de este libro que consideramos de obligada e imprescindible lectura.

Patricia Trapero Llobera Universitat de les Illes Balears 
